\title{
Analisis Teknik dan Metode Penerjemahan Al-Qur'an dan Terjemahannya versi Kementerian Agama dalam Ayat-ayat Khawatim Al-Suwar
}

\author{
M. Fahri Andrianto ${ }^{1}$, M.R. Nababan ${ }^{2}$, Eva Farhah ${ }^{3}$ \\ ${ }^{1,2,3}$ Universitas Sebelas Maret, Jl. Ir. Sutami No.36, Kentingan, Kec. Jebres, Kota Surakarta, Jawa Tengah \\ 57126 \\ Correspondence: M. Fahri Andrianto (fahriandrianto@student.uns.ac.id) \\ Received: 140721 - Revised: 190721 - Accepted: 190721 - Published: 261021
}

\begin{abstract}
Abstrak. Penelitian ini bertujuan untuk mengetahui teknik penerjemahan serta metode penerjemahan AlQur'an dan terjemahannya versi Kementerian Agama RI edisi penyempurnaan 2019 dalam ayat-ayat Khawatim al-Suwar. Untuk mengumpulkan data dilakukan observasi dan FGD. Hasil analisis mengungkapkan bahwa ada 13 teknik penerjemahan yang diterapkan. Teknik yang paling dominan dalam analisis ini adalah teknik kesepadanan lazim karena tidak dapat dipisahkan dari konteksnya. Temuan dari analisis menunjukkan bahwa metode komunikatif adalah metode yang paling berorientasi. Hal ini dapat dibuktikan dengan mengetahui rata-rata total teknik penerjemahan yang digunakan. Metode komunikatif memiliki persentase sebesar $99,88 \%$ dari teknik penerjemahan yang digunakan. Kemudian sisanya sebesar $0,12 \%$ teknik penerjemahan mencerminkan metode setia.
\end{abstract}

Kata kunci: Khawatim al-Suwar, Teknik Penerjemahan, Metode Penerjemahan, Penerjemahan Al-Quran, Kementerian Agama.

Citation Format: Andrianto, M.F., Nababan, M.R. \& Farhah, E. (2021). Analisis Teknik dan Metode Penerjemahan Al-Qur'an dan Terjemahannya versi Kementerian Agama dalam Ayat-ayat Khawatim Al-Suwar. Prosiding Seminar Nasional Abdimas Ma Chung (SENAM), 2021, 117-130. 


\section{PENDAHULUAN}

Dalam sejarah penulisan Al-Qur'an terjemahan dalam bahasa Indonesia versi kemenag, Kementerian Agama membentuk tim Lajnah Pentashihan Mushaf Al-Qur'an. Sejak diterbitkan pertama kali pada tahun 1965, terjemahan Al-Qur'an telah mengalami revisi dan penyempurnaan sebanyak dua kali. Penyempurnaan pertama dilakukan pada tahun 1989 yang difokuskan pada aspek redaksional. Pada tahun 1998-2002 dilakukan perbaikan dan penyempurnaan secara menyeluruh, mencakup aspek bahasa, konsistensi, substansi, dan transliterasi. Seiring perkembangan bahasa Indonesia dan adanya masukan dari masyarakat terkait substansi terjemahan, pada tahun 2016-2019 Lajnah Pentashihan Mushaf Al-Qur'an kembali melakukan kajian dan pengembangan terjemahan Al-Qur'an Kementerian Agama yang mencakup berbagai aspek meliputi aspek bahasa, konsistensi dan substansi. Di samping aspek tersebut, terjemahan Al-Qur'an hasil penyempurnaan ini juga dilengkapi dengan mukadimah yang memuat sistematika dan metode penerjemahan (Kementerian Agama, 2019). Berdasarkan hal tersebut, peneliti tertarik untuk mengkaji terjemahan Al-Qur'an versi penyempurnaan terbaru dari Kementerian Agama ini, dengan objek pembahasan salah satu bidang ilmu dalam keilmuan Al-Qur'an yaitu Khawatim alSuwar.

Tim Lajnah Pentashihan Mushaf Al-Qur'an menyatakan bahwa mereka menggunakan metode penerjemahan setia dalam menerjemahkan Al-Qur'an, yang berarti sedapat mungkin mempertahankan atau setia pada isi dan bentuk bahasa sumber (BSu). Lafal yang dapat diterjemahkan secara harfiah, diterjemahkan secara harfiah. Sedangkan yang tidak, diterjemahkan secara interpretatif, baik berupa pemberian catatan kaki maupun tambahan penjelasan di dalam tanda kurung (Kementerian Agama, 2019, hlm. vi). Berdasarkan pernyataan tersebut, Lajnah Pentashihan Mushaf Al-Qur'an 1965-2019 melakukan kajian dan pengembangan terjemahan Al-Qur'an, tanpa menganalisis dan mendeskripsikan teknik penerjemahan yang mereka gunakan dalam menerjemahkan AlQur'an, yang merupakan proses mikro dalam penerjemahan.

Teknik penerjemahan adalah alat yang digunakan untuk mengalihkan pesan dari bahasa sumber ke dalam bahasa sasaran menggunakan istilah, frasa, klausa, atau kalimat. Menurut Molina dan Albir (2002), teknik penerjemahan memiliki lima ciri; (1) teknik penerjemahan mempengaruhi hasil penerjemahan; (2) teknik diklasifikasikan berdasarkan perbandingan dalam teks bahasa sasaran; (3) tekniknya pada level mikro; (4) tekniknya tidak saling terkait tetapi berdasarkan konteks tertentu; (5) tekniknya fungsional. Molina 
dan Albir mengusulkan delapan belas (18) teknik penerjemahan; yaitu: adaptasi, amplifikasi berupa explisitasi, adisi, dan parafrase, peminjaman berupa peminjaman murni dan peminjaman naturalisasi, kalke, kompensasi, deskripsi, kreasi diskursif, kesepadanan lazim, generalisasi, amplifikasi linguistik, kompresi linguistik, penerjemahan literal (harfiah), modulasi, partikularisasi, reduksi berupa implisitasi dan omisi, subtitusi, transposisi, and variasi.

Nababan (2008) mendefinisikan metode penerjemahan sebagai pilihan global yang dipilih oleh seorang penerjemah untuk menyelesaikan proyek penerjemahan. Dengan demikian, metode penerjemahan merupakan orientasi yang ingin dicapai penerjemah dalam penerjemahannya. Menurut Newmark (1988), metode penerjemahan dibagi menjadi dua kelompok besar, (1) metode yang menekankan pada bahasa sumber (BSu); seperti penerjemahan kata demi kata, literal, setia, dan semantik, dan (2) metode yang menekankan pada bahasa sasaran (BSa); seperti terjemahan adaptasi, bebas, idiomatik, dan komunikatif, seperti yang digambarkan pada diagram $\mathrm{V}$ di bawah ini:

Tabel 1. V Diagram Translation Methode (Newmark)

\begin{tabular}{|c|c|}
\hline SL Emphasis & TL Emphasis \\
\hline Word-for-word & Adaptation \\
\hline Literal translation & Free translation \\
\hline Faithful translation & Idiomatic translation \\
\hline Semantic translation & Communicative translation \\
\hline
\end{tabular}

Kajian tentang terjemahan Al-Qur'an Kementerian Agama RI, khususnya tentang metode penerjemahan masih terbatas. Pembahasan yang dilakukan adalah tentang teknik penerjemahan dan kualitas terjemahannya (Annisaa et al., 2020), (Gunawan, 2019), (Kurniawan, 2019). Kajian yang mengaitkan teknik penerjemahan dan metode penerjemahannya baru membahas tentang Fawatih al-Suwar, yang merupakan salah satu bidang ilmu Al-Qur'an (Andrianto et al., 2021). Selain itu, penelitian tentang Khawatim alSuwar juga terbatas pada persoalan bagaimana masyarakat memahami makna ayat-ayat Khawatim al-Suwar (Nuryana, 2003). Oleh karena itu, belum ada satu pun penelitian yang fokus membahas Khawatim al-Suwar dari perspektif teknik penerjemahan dan metode penerjemahan.

Untuk mengisi celah penelitian, artikel ini bertujuan untuk membahas dua topik; yaitu bagaimana teknik penerjemahan yang digunakan oleh Kementerian Agama RI dan implikasi teknik penerjemahan yang digunakan terhadap metode penerjemahan pada ayat- 
ayat Khawatim al-Suwar. Penerjemahan ayat-ayat Khawatim al-Suwar dipilih karena keistimewaannya yang merupakan penutup ayat-ayat pada setiap surat di dalam Al-Qur'a

\section{METODE PELAKSANAAN}

Penelitian ini merupakan kajian penerjemahan terhadap produk terjemahan Kementerian Agama RI. Berdasarkan Santosa (2017), penelitian ini menggunakan deskriptif kualitatif karena mendeskripsikan fenomena kebahasaan dalam teknik dan metode penerjemahan Khawatim al-Suwar dalam Al-Qur'an. Data penelitian diperoleh dari setiap ayat penutup pada setiap surah di dalam Al-Qur'an dengan jumlah 114 ayat dan dianalisis. Teknik pengumpulan data menggunakan analisis isi dan focus group discussion (FGD). Analisis isi digunakan untuk mendapatkan data. FGD yang melibatkan rater yang ahli dalam kajian penerjemahan dan penerjemahan bahasa Arab dilakukan untuk mengidentifikasi teknik dan metode penerjemahan. Peneliti juga terlibat dalam FGD. Data dari penelitian ini dianalisis menggunakan dua kerangka; teknik penerjemahan oleh Molina dan Albir (2002) dan metode penerjemahan oleh Newmark (1988).

\section{HASIL DAN PEMBAHASAN}

\section{Temuan}

\section{Teknik Penerjemahan dalam Khawatim al-Suwar}

Berdasarkan hasil FGD, ditemukan bahwa teknik penerjemahan yang digunakan tim Lajnah Pentashihan Mushaf Al-Qur'an dalam menerjemahkan ayat-ayat Khawatim alSuwar adalah sebagai berikut: kesepadanan lazim (68.14\%), amplifikasi (explisitasi) (14.06\%), reduksi (implisitasi) (6.07\%), kompensasi (4.43\%), variasi (2.16\%), amplifikasi (adisi) (1.87\%), modulasi (1.11\%), transposisi (0.82\%), amplifikasi (parafrase) (0.76\%), amplifikasi (anotasi) (0.29\%), generalisasi (0.17\%), literal (0.06\%) dan peminjaman (murni) $(0.06 \%)$. Penggunaan teknik penerjemahan teks Al-Qur'an dalam ayat-ayat Khawatim al-Suwar akan dijelaskan sebagaimana berikut:

Table 1: Teknik Penerjemahan dalam Khawatim al-Suwar

\begin{tabular}{l|c|c}
\multicolumn{1}{c|}{ Teknik penerjemahan } & Frekuensi & $\%$ \\
\hline Kesepadanan Lazim & 1168 & 68,14 \\
\hline Amplifikasi (Eksplisitasi) & 241 & 14,06 \\
\hline Reduksi (Implisitasi) & 104 & 6,07 \\
\hline Kompensasi & 76 & 4,43 \\
\hline Variasi & 37 & 2,16 \\
\hline Amplifikasi (Adisi) & 32 & 1,87 \\
\hline Modulasi & 19 & 1,11 \\
\hline Transposisi & 14 & 0,82 \\
\hline
\end{tabular}




\begin{tabular}{l|c|c}
\hline Amplifikasi (Parafrase) & 13 & 0,76 \\
\hline Amplifikasi (Anotasi) & 5 & 0,29 \\
\hline Generalisasi & 3 & 0,17 \\
\hline Literal & 1 & 0,06 \\
\hline Peminjaman (Murni) & 1 & 0,06 \\
\hline
\end{tabular}

\section{Teknik kesepadanan lazim}

Padanan lazim adalah teknik untuk menggunakan istilah atau ekspresi yang sudah dikenal (berdasarkan kamus atau penggunaan sehari-hari) dalam bahasa sasaran (Molina dan Albir, 2002). Dalam penerapannya, teknik ini memberikan pemilihan makna kata secara leksikal dengan memberikan padanan makna kata yang tepat melalui pemahaman yang cermat terhadap makna bahasa sumber, yang merupakan bagian dari aspek transfer. Jika aspek pemilihan makna leksikal tidak tepat, maka akan menyebabkan ketidakakuratan pesan dalam terjemahan bahasa sasaran. Aspek acuan endopora berperan sangat penting dalam membentuk konteks yang merujuk pada makna dengan teknik padanan lazim, baik dalam bahasa sumber maupun bahasa sasaran. Dalam ayat-ayat Khawatim alSuwar, teknik kesepadanan lazim digunakan sebanyak 1168 kali dan berikut adalah contoh data dari domain Khawatim al-Suwar:

\section{Q.S 101: 11/K101}

\begin{tabular}{lll}
\hline Bahasa Sumber & $:$ & نَارُ حَامِيَّة \\
\hline Transliterasi & $:$ & nārun hāmiyah \\
\hline Bahasa Sasaran & $:$ & (Ia adalah) api yang sangat panas \\
\hline
\end{tabular}

Pada data di atas, kata nārun diterjemahkan menjadi 'api'. Istilah tersebut sudah lazim digunakan oleh masyarakat pada umumnya dan juga lazim digunakan di dalam kamus (Kamus Munawwir, 2007, hal. 1474). Maka dalam hal ini penerjemah menggunakan teknik kesepadanan lazim dalam menerjemahkan kata-kata tersebut.

\section{Teknik amplifikasi}

Amplifikasi adalah teknik penerjemahan yang mengungkapkan atau memparafrasekan informasi implisit dalam bahasa sumber. Amplifikasi dapat berupa eksplisitasi, penambahan, anotasi, dan parafrase. Teknik ekplisitasi adalah teknik penerjemahan yang sedikit menjelaskan istilah-istilah yang tidak jelas. Teknik ini membantu meningkatkan keterbacaan atau pemahaman pembaca teks yang diterjemahkan. 
Dalam Kamus Besar Bahasa Indonesia, eksplisit berarti tegas dan tidak berbelit-belit (KBBI, 2008, hal. 379). Sebuah kata yang masih belum jelas, khususnya kata ganti, diperjelas secara eksplisit. Dalam ayat-ayat Khawatim al-Suwar, teknik eksplisitasi digunakan sebanyak 241 kali dan berikut adalah contoh data dari domain Khawatim alSuwar:

\section{Q.S 69:52/K069}

\begin{tabular}{|c|c|}
\hline Bahasa Sumber & 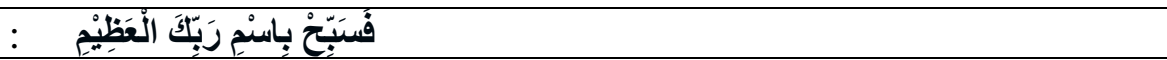 \\
\hline Transliterasi & : fa sabbih bismi rabbikal 'aẓim \\
\hline Bahasa Sasaran & $\begin{array}{l}\text { Maka, bertasbihlah dengan (menyebut) nama Tuhanmu Yang } \\
\text { Mahaagung }\end{array}$ \\
\hline
\end{tabular}

Pada data di atas, kata bismi diterjemahkan menjadi 'dengan (menyebut) nama'. Jika dilihat dari bahasa sumber, kata bismi bermakna 'dengan nama', tanpa ada tambahan kata menyebut. Penerjemah menambahkan kata tersebut untuk memberikan penjelasan agar lebih mudah dipahami oleh pembaca.

Kemudian, dalam ayat-ayat Khawatim al-Suwar, teknik penambahan digunakan sebanyak 32 kali dan berikut adalah contoh data dari domain Khawatim al-Suwar:

\section{Q.S 105:5/K105}

\begin{tabular}{|c|c|}
\hline Bahasa Sumber & 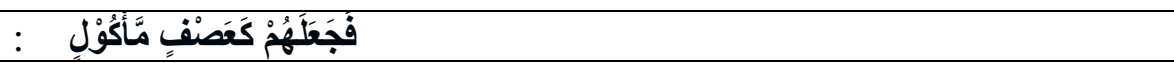 \\
\hline Transliterasi & : faja'alahum ka'așfim ma`kụl \\
\hline Bahasa Sasaran & $\begin{array}{l}\text { sehingga Dia (Allah) menjadikan mereka seperti daun-daun } \\
\text { yang dimakan (ulat) }\end{array}$ \\
\hline
\end{tabular}

Pada data di atas, kata faja'alahum diterjemahkan menjadi 'sehingga Dia (Allah) menjadikan mereka'. Penerjemah dalam hal ini memberikan keterangan tambahan untuk menjelaskan kata Dia bahwa yang dimaksudkan adalah Allah, sehingga pembaca bisa lebih mudah dalam memahami terjemahannya.

Teknik parafrase adalah teknik penerjemahan yang mengungkapkan kembali suatu konsep dalam bahasa yang sama dengan cara lain, tetapi tidak mengubah maknanya. Dalam ayat-ayat Khawatim al-Suwar, teknik parafrase digunakan sebanyak 13 kali dan berikut adalah contoh data dari domain Khawatim al-Suwar:

\section{Q.S 76:31/K076}




\begin{tabular}{|c|c|}
\hline Bahasa Sumber & 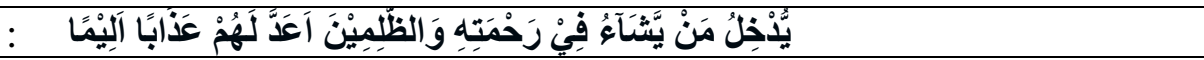 \\
\hline Transliterasi & $\begin{array}{l}\text { yudkhilu may yasyā'u fĩ raḥmatih, waz-ẓālimīna a'adda lahum } \\
\text { 'ażāban alīmā }\end{array}$ \\
\hline Baha: & $\begin{array}{l}\text { Dia memasukkan siapa pun yang Dia kehendaki ke dalam rahmat- } \\
\text { Nya (surga). Bagi orang-orang zalim Dia sediakan azab yang } \\
\text { pedih }\end{array}$ \\
\hline
\end{tabular}

Pada data di atas, kalimat waz-zâlimīna a'adda lahum 'ażāban alīmā dalam bahasa sumber diterjemahkan ke dalam bahasa sasaran menjadi 'bagi orang-orang zalim Dia sediakan azab yang pedih'. Jika dilihat dalam bahasa sumber, kalimat waz-zāilimīna a'adda lahum 'ażāban alīmā bermakna 'adapun orang-orang zalim Dia menyediakan bagi mereka azab yang pedih'. Dalam hal ini penerjemah menggunakan teknik parafrase agar bahasa yang dipakai lebih sederhana dan memudahkan pembaca dalam memahami terjemahan AlQur'an khususnya dalam ayat ini.

Selanjutnya, dalam ayat-ayat Khawatim al-Suwar, teknik anotasi digunakan sebanyak 5 kali dan berikut adalah contoh data dari domain Khawatim al-Suwar:

\section{Q.S 38:88/K038}

\begin{tabular}{|c|c|}
\hline Bahasa Sumber & 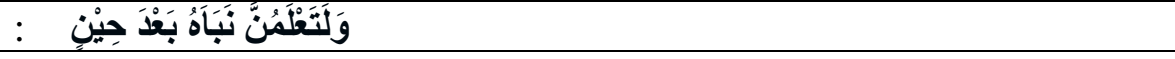 \\
\hline Transliterasi & : wa lata'lamunna naba`ahụ ba'da hīn \\
\hline Bahasa Sasar & $\begin{array}{l}\text { Sungguh, kamu akan mengetahui (kebenaran) beritanya (Al- } \\
\text { Qur'an) setelah beberapa waktu lagi }\end{array}$ \\
\hline
\end{tabular}

Pada data di atas, setelah menerjemahkan ayat tersebut secara keseluruhan, penerjemah menambahkan anotasi di akhir ayat untuk memberikan keterangan tambahan yang menjelaskan tentang kebenaran Al-Qur'an, dengan tujuan agar pembaca mendapatkan penjelasan yang lebih detail terhadap ayat tersebut.

\section{Teknik implisitasi}

Teknik implisit adalah teknik yang menyarankan detail tertentu dalam teks bahasa sasaran dalam bahasa sumber. Dalam ayat-ayat Khawatim al-Suwar, teknik implisitasi digunakan sebanyak 104 kali dan berikut adalah contoh data dari domain Khawatim alSuwar:

\section{Q.S 37:182/K037}

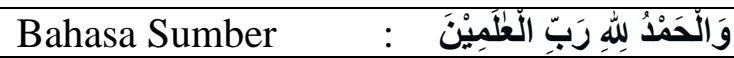


Transliterasi $\quad: \quad$ wal-ḥamdu lillāhi rabbil 'ālamīn

Bahasa Sasaran $\quad$ : Segala puji bagi Allah Tuhan semesta alam

Pada data di atas, kata wal-hamdu diterjemahkan menjadi 'segala puji'. Jika dilihat dari bahasa sumber, kata wal-hamdu bermakna 'dan segala puji'. Penerjemah disini menghilangkan kata 'dan' dengan tujuan memudahkan pemahaman terhadap terjemahan tersebut. Maka, disini penerjemah menggunakan teknik implisitasi untuk mendapatkan hasil terjemahan yang lebih baik.

\section{Teknik kompensasi}

Teknik kompensasi adalah teknik penerjemahan yang mentransfer pesan ke bagian lain dari teks yang diterjemahkan. Ini juga berarti bahwa penerjemah memperkenalkan unsur-unsur informasi atau pengaruh stilistika teks bahasa sumber di tempat lain dalam teks bahasa sasaran. Dalam ayat-ayat Khawatim al-Suwar, teknik kompensasi digunakan sebanyak 76 kali dan berikut adalah contoh data dari domain Khawatim al-Suwar:

\section{Q.S 99:8/K099}

\begin{tabular}{|c|c|c|}
\hline Bahasa Sumber & & 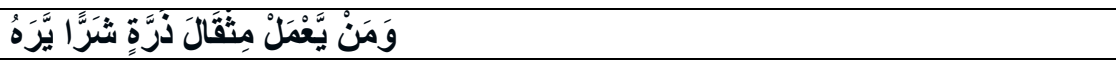 \\
\hline Transliterasi & & wa may ya'mal mis̀qāla żarratin syarray yarah \\
\hline Bahasa Sasar & & $\begin{array}{l}\text { Siapa yang mengerjakan kejahatan seberat zarah, dia akan } \\
\text { melihat (balasan)-nya }\end{array}$ \\
\hline
\end{tabular}

Pada data di atas, kalimat may ya'mal misqāla żarratin syarran diterjemahkan menjadi 'siapa yang mengerjakan kejahatan seberat zarah'. Kata syarran yang bermakna 'kejahatan' didahulukan penyebutannya dari kata miśqāla żarratin yang bermakna 'seberat zarah'. Penerjemah menggunakan teknik kompensasi dengan mendahulukan penyebutan makna kata 'syarran' agar lebih memudahkan pembaca dalam memahami terjemahan AlQur'an.

\section{Teknik variasi}

Dalam ayat-ayat Khawatim al-Suwar, teknik variasi digunakan sebanyak 37 kali dan berikut adalah contoh data dari domain Khawatim al-Suwar:

\section{Q.S 36:83/K036}

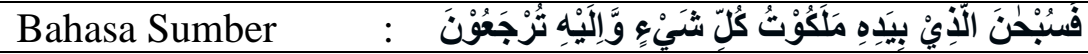




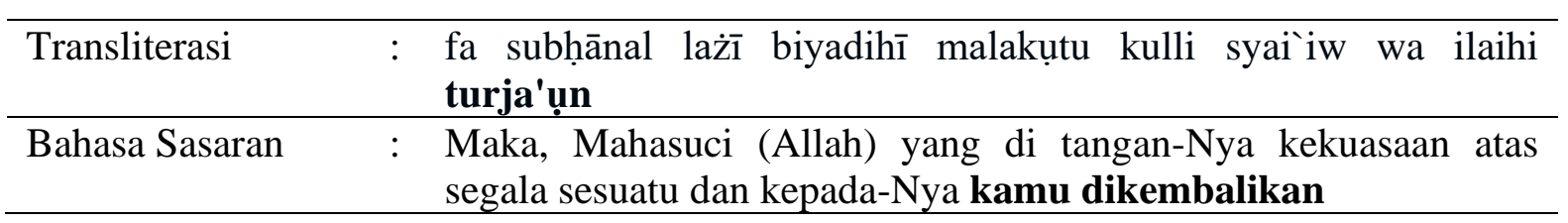

Pada data di atas, kata turja'ụn diterjemahkan menjadi 'kamu dikembalikan'. Jika dilihat dari bahasa sumber, kata turja'ụn bemakna 'kamu semua dikembalikan' atau 'kalian dikembalikan'. Sebab objek yang dimaksudkan pada kata ini adalah seluruh manusia yang berarti berjumlah lebih dari 2 orang. Tapi penerjemah dalam ayat ini memilih untuk menggunakan kata yang lebih mudah dengan menggunakan kata kamu saja.

\section{Teknik modulasi}

Modulasi adalah teknik penerjemahan di mana penerjemah mengubah sudut pandang, fokus, atau kategori kognitif bahasa sumber. Perubahan dapat terjadi dalam bentuk gramatikal dan leksikal. Dalam ayat-ayat Khawatim al-Suwar, teknik modulasi digunakan sebanyak 19 kali dan berikut adalah contoh data dari domain Khawatim alSuwar:

\section{Q.S 90:20/K090}

\begin{tabular}{|c|c|}
\hline Bahasa Sumber & 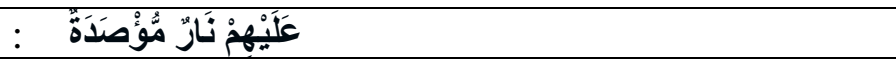 \\
\hline Transliterasi & : 'alaihim nārum mu`șadah \\
\hline Bahasa Sasaran & : Mereka berada dalam neraka yang ditutup rapat \\
\hline
\end{tabular}

Pada data di atas, kata 'alaihim diterjemahkan menjadi 'mereka berada'. Jika dilihat dari bahasa sumber, kata 'alaihim bermakna 'atas mereka'. Tapi penerjemah dalam hal ini menggunakan teknik modulasi sehingga kata 'alaihim yang bermakna 'atas mereka' digantikan dengan 'mereka berada' dan merubah sudut pandang terjemahan dalam bahasa sumber.

\section{Teknik transposisi}

Teknik transposisi adalah teknik yang menggantikan tatanan struktural bahasa sasaran. Dalam ayat-ayat Khawatim al-Suwar, teknik transposisi digunakan sebanyak 14 kali dan berikut adalah contoh data dari domain Khawatim al-Suwar:

\section{Q.S 64:18/K064}




\begin{tabular}{|c|c|}
\hline Bahasa Sumber & 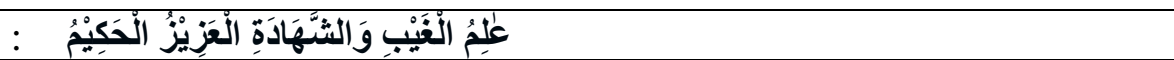 \\
\hline Transliterasi & : 'ālimul gaibi wasy-syahādatil 'azīzul ḥakīm \\
\hline Bahasa Sasar & $\begin{array}{l}\text { Dialah yang mengetahui semua yang gaib dan yang nyata. } \\
\text { (Dialah) Yang Mahaperkasa lagi Mahabijaksana }\end{array}$ \\
\hline
\end{tabular}

Pada data di atas, kata 'ālimul yang bermakna 'yang mengetahui' diterjemahkan menjadi 'Dialah yang mengetahui'. Penerjemah disini merubah struktur gramatikal bahasa sumber dengan menambahkan kata 'Dialah'. Dengan demikian, subjek mendapatkan keterangan tambahan, tetapi tidak menghilangkan makna sebenarnya dari bahasa sumber. Penerjemah menggunakan teknik transposisi untuk memudahkan pembaca dalam memahami terjemahan Al-Qur'an.

\section{Teknik generalisasi}

Dalam ayat-ayat Khawatim al-Suwar, teknik generalisasi digunakan sebanyak 3 kali dan berikut adalah contoh data dari domain Khawatim al-Suwar:

\section{Q.S 78:40/K078}

\begin{tabular}{|c|c|}
\hline Bahasa Sumber & 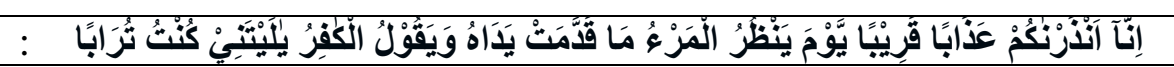 \\
\hline Transliterasi & $\begin{array}{l}\text { innā anżarnākum 'ażāban qarībay yauma yanzurul-mar`u māe } \\
\text { qaddamat yadāhu wa yaqụlul-kāfiru yā laitanī kuntu turābā }\end{array}$ \\
\hline Bahasa Sasaran & $\begin{array}{l}\text { Sesungguhnya Kami telah memperingatkan kamu akan azab yang } \\
\text { dekat pada hari (ketika) manusia melihat apa yang telah } \\
\text { diperbuat oleh kedua tangannya dan orang kafir berkata, "Oh, } \\
\text { seandainya saja aku menjadi tanah }\end{array}$ \\
\hline
\end{tabular}

Pada data di atas, kata mar`u dalam bahasa sumber diterjemahkan ke dalam bahasa sasaran menjadi 'manusia'. Jika dilihat dalam bahasa sumber, kata mar`u bermakna 'seseorang'. Penerjemah disini memilih menggunakan kata manusia dalam menerjemahkan kata mar`u. Peralihan kata dari seseorang menjadi manusia merupakan proses generalisasi, sehingga penerjemah menggunakan teknik tersebut untuk mendapatkan terjemahan yang lebih baik dan memudahkan pemahaman bagi pembaca.

\section{Teknik literal (penerjemahan harfiah)}

Dalam ayat-ayat Khawatim al-Suwar, teknik literal (penerjemahan harfiah) digunakan sebanyak 1 kali dan berikut adalah contoh data dari domain Khawatim alSuwar: 


\section{Q.S 74:56/K074}

\begin{tabular}{|c|c|}
\hline Bahasa Sumber & 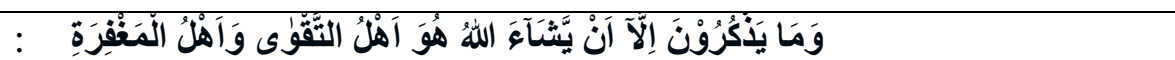 \\
\hline Transliterasi & $\begin{array}{l}\text { : wa mā yażkurụna illā ay yasyā'allāh, huwa ahlut-taqwā wa } \\
\text { ahlul-magfirah }\end{array}$ \\
\hline Bahasa Sasaran & $\begin{array}{l}\text { Mereka tidak akan mengambil pelajaran darinya (Al-Qur'an), } \\
\text { kecuali (jika) Allah menghendakinya. Dialah yang (kita) patut } \\
\text { bertakwa kepada-Nya dan yang berhak memberi ampunan }\end{array}$ \\
\hline
\end{tabular}

Pada data di atas, kata ahlut-taqwā dalam bahasa sumber diterjemahkan ke dalam bahasa sasaran menjadi 'yang (kita) patut bertakwa kepada-Nya'. Jika dilihat dalam bahasa sumber, kata ahlut-taqwā bermakna 'orang-orang yang bertakwa'. Tapi penerjemah dalam ayat ini menerjemahkannya secara harfiah karena secara konteks terjemahan yang dihasilkan lebih sesuai dan bisa dipahami oleh masyarakat.

\section{Teknik peminjaman (murni)}

Dalam ayat-ayat Khawatim al-Suwar, teknik Peminjaman Murni digunakan sebanyak 1 kali dan berikut adalah contoh data dari domain Khawatim al-Suwar:

\section{Q.S 4:176/K004}

\begin{tabular}{|c|c|c|}
\hline Bahasa Sumber & : & 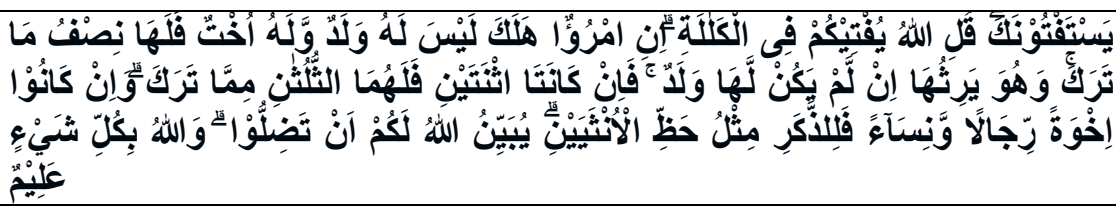 \\
\hline Tran & & 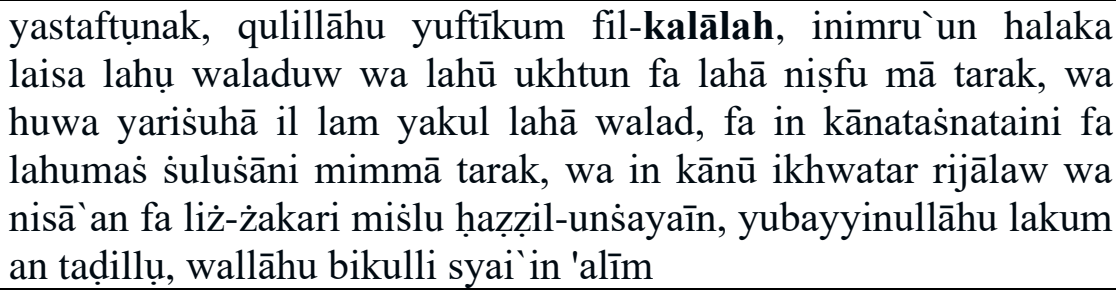 \\
\hline Bahasa Sasaran & : & $\begin{array}{l}\text { Mereka meminta fatwa kepadamu (tentang kalālah). Katakanlah, } \\
\text { "Allah memberi fatwa kepadamu tentang kalälah (yaitu,) jika } \\
\text { seseorang meninggal dan dia tidak mempunyai anak, tetapi } \\
\text { mempunyai seorang saudara perempuan, bagiannya (saudara } \\
\text { perempuannya itu) seperdua dari harta yang ditinggalkannya. } \\
\text { Adapun saudara lakilakinya mewarisi (seluruh harta saudara } \\
\text { perempuan) jika dia tidak mempunyai anak. Akan tetapi, jika } \\
\text { saudara perempuan itu dua orang, bagi keduanya dua pertiga dari } \\
\text { harta yang ditinggalkan. Jika mereka (ahli waris itu terdiri atas) } \\
\text { beberapa saudara laki-laki dan perempuan, bagian seorang } \\
\text { saudara laki-laki sama dengan bagian dua orang saudara } \\
\text { perempuan. Allah menerangkan (hukum ini) kepadamu agar }\end{array}$ \\
\hline
\end{tabular}


kamu tidak tersesat. Allah Maha Mengetahui segala sesuatu

Pada data di atas, kata kalālah diterjemahkan ke dalam bahasa sasaran menjadi sama dengan kata aslinya, yaitu: 'kalālah' dikarenakan tidak ada padanan yang tepat dalam bahasa sasaran untuk menerjemahkan kata tersebut. Sehingga meminjam kata terjemahan dari bahasa sumber merupakan kebijakan yang tepat untuk menerjemahkan kata tersebut.

\section{Pembahasan}

Metode penerjemahan memiliki keterkaitan yang kuat dengan teknik penerjemahan. Molina \& Albir (2002) menyatakan bahwa metode penerjemahan adalah cara proses penerjemahan tertentu dilakukan dalam kaitannya dengan tujuan penerjemah, opsi global yang mempengaruhi keseluruhan teks. Berdasarkan hasil FGD, teknik kesepadanan lazim, amplifikasi, implisitasi, kompensasi, variasi, modulasi, transposisi, dan generalisasi adalah teknik penerjemahan yang merefleksikan metode komunikatif sebagai metode yang paling berorientasi. Dalam ayat-ayat Khawatim al-Suwar, ada 99,88 persen data yang berorientasi pada metode komunikatif. Sisanya sekitar 0,12 persen data berorientasi pada metode setia yang direfleksikan dari teknik literal dan peminjaman murni.

Temuan penelitian ini memperkuat penelitian yang dilakukan sebelumnya (Andrianto et al., 2021) yang menyatakan bahwa tim Lajnah Pentashihan Mushaf AlQur'an menggunakan teknik penerjemahan yang lebih berorientasi kepada metode penerjemahan komunikatif. Sementara itu, tim Lajnah Pentashihan Mushaf Al-Qur'an sebagai tim penerjemah Kementerian Agama RI berpendapat bahwa mereka menggunakan metode penerjemahan setia untuk menerjemahkan Al-Qur'an dari bahasa sumber (BSu) ke dalam bahasa sasaran (BSa). Dalam hal ini, terdapat hasil yang berbeda antara pernyataan tim Lajnah Pentashihan Mushaf Al-Qur'an dengan temuan penelitian ini.

Meskipun objek penelitian ini tidak mencakup semua ayat dalam Al-Qur'an, pembahasan ini dapat menjadi perbandingan dengan hasil terjemahan yang telah dilakukan oleh Kementerian Agama RI. Tim Lajnah Pentashihan Mushaf Al-Qur'an sebagai tim penerjemah dari Kementerian Agama RI melakukan kajian dan pengembangan terjemahan Al-Qur'an berdasarkan pernyataan menerjemahkan Al-Qur'an dengan metode setia atau diterjemahkan secara harfiah, tanpa menganalisis dan mendeskripsikan teknik penerjemahan yang mereka gunakan dalam menerjemahkan AlQur'an, sebagai proses mikro pada penerjemahan. Kemudian, ketika kajian ini melakukan 
penelitian dari proses mikro pada penerjemahan, ditemukan bahwa teknik penerjemahan yang digunakan oleh tim Lajnah Pentashihan Mushaf Al-Quran lebih berorientasi kepada metode penerjemahan komunikatif. Hal ini dapat dibuktikan dengan teknik kesepadanan lazim sebagai teknik yang paling banyak digunakan oleh tim penerjemah karena tidak lepas dari konteksnya. Apalagi teknik penerjemahan yang berorientasi pada metode penerjemahan setia hanya dicerminkan oleh teknik literal dan peminjaman murni yang terdapat dalam 2 data pada penelitian ini.

\section{KESIMPULAN}

Penelitian ini bertujuan untuk mengetahui teknik penerjemahan dan mengetahui implikasinya terhadap metode penerjemahan Al-Qur'an dan terjemahannya versi Kementerian Agama pada ayat-ayat Khawatim al-Suwar. Teknik penerjemahan yang digunakan oleh tim Lajnah Pentashihan Mushaf Al-Qur'an sebagai tim penerjemah dari Kementerian Agama RI adalah sebagai berikut; kesepadanan lazim (68.14\%), amplifikasi (explisitasi) (14.06\%), reduksi (implisitasi) (6.07\%), kompensasi (4.43\%), variasi $(2.16 \%)$, amplifikasi (adisi) (1.87\%), modulasi (1.11\%), transposisi (0.82\%), amplifikasi (parafrase) $(0.76 \%)$, amplifikasi (anotasi) $(0.29 \%)$, generalisasi $(0.17 \%)$, literal $(0.06 \%)$ dan peminjaman (murni) (0.06\%). Hasil ini menunjukkan bahwa kesepadanan lazim adalah teknik penerjemahan yang paling dominan. Selanjutnya, total teknik penerjemahan mencerminkan bahwa metode komunikatif adalah metode yang paling berorientasi. Dapat disimpulkan bahwa terjemahan Al-Qur'an Kementerian Agama RI sebagian besar berorientasi kepada metode komunikatif. Sementara itu, hanya data terjemahan yang dihasilkan oleh teknik penerjemahan literal dan peminjaman murni yang mencerminkan metode setia.

\section{DAFTAR RUJUKAN}

Andrianto, M. F., Nababan, M. R., \& Farhah, E. (2021). The Impact of Translation Techniques on Translation methods of Qur'an Translation of Indonesian Ministry of Religion on Fawatih al-Suwar. International Journal of Linguistics, Literature and Translation, 4(6), 291-298. https://doi.org/10.32996/ijllt.2021.4.6.34

Annisaa, I., Nababan, M. R., \& Djatmika, D. (2020). Analisis Kualitas Keterbacaan Pada Quran Surat Al- Kahfi Ayat 1-10 Dalam Dua Versi Terjemahan (Depag RI Dan MMI). KoPeN: Konferensi Pendidikan Nasional. 2(1), 131-136.

Gunawan, F. (2019). The Effect of Translation Technique to Its Quality at The Holy Book of Indonesian Moslem Society. Lisan: Jurnal Bahasa dan Linguistik. 8(2), 101-109. https://doi.org/10.33506/li.v8i2.377 
Kementerian Agama RI. (2019). Al-Qur'an dan Terjemahannya, Edisi Penyempurnaan 2019. Jakarta.

Kurniawan, D.C. (2019). Analisis teknik penerjemahan dhomir (pronomina) dan 'athaf (konjungsi) pada kisah Nabi Musa dalam al-Qur'an surah Ta-Ha dan kualitas terjemahannya. (Tesis). Universitas Sebelas Maret: Surakarta.

Molina, L., \& Albir, A. H. (2002). 'Translation techniques revisited: A dynamic and functionalist approach'. Meta: Journal Des Traducteurs/Meta: Translators' Journal. 47(4), 498-512.

Munawwir, A.W. 2007. Kamus Al-Munawwir Arab-Indonesia Terlengkap. Yogyakarta: Pustaka Progresif.

Nababan, M. R. (2008). Teori menerjemah bahasa inggris. Yogyakarta: Pustaka Pelajar.

Newmark, P. (1988). A Textbook of Translation. New York: Prentice Hall Inc.

Nuryana, Y. (2003). Korelasi fawatih al-suwar dan khawatim al-suwar dalam al-Qur'an (Studi terhadap surat-surat dalam al-Tiwal). (Skripsi). Universitas Islam Negeri Sunan Kalijaga: Yogyakarta.

Santosa, R. (2017). Metode penelitian kualitatif kebahasaan. Surakarta: Universitas Sebelas Maret. UNS Press.

Tim Penyusun Kamus Pusat Bahasa. (2008). Kamus Bahasa Indonesia, Edisi 4. Jakarta: Pusat Bahasa.

(C) 2021 by authors. Content on this article is licensed under a Creative Commons Attribution 4.0 International license. (http://creativecommons.org/licenses/by/4.0/). 